\title{
PARADIGMA KEAGAMAAN DOSEN PENDIDIKAN AGAMA ISLAM DI UNIVERSITAS TIRTAYASA BANTEN
}

\section{RELIGIOUS PARADIGM LECTURER OF ISLAMIC RELIGIOUS EDUCATION AT TIRTAYASA UNIVERSITY, BANTEN}

\author{
Huriyudin \\ ${ }^{I}$ Puslitbang Pendidikan Agama dan Keagamaan, Badan Litbang dan Diklat Kementerian Agama RI \\ email: huriyudin@gmail.com
}

Naskah Diterima: 12 November 2021; Direvisi: 16 November 2021; Disetujui: 12 Desember 2021

\begin{abstract}
This study aims to explain the religious paradigm of lecturers in Islamic religious education at Tirtayasa University, Banten, using a qualitative approach. The research was conducted from April to June 2021. Data collection techniques used interviews, and content analysis. The informants involved were all lecturers of Islamic religious education. This study found that there were variations in religious paradigms, educational background and scientific interests, access to sources and reading materials, as well as religious styles adopted. The book used contains an acute problem related to the problem of religious moderation. The discussion on the themes of monotheism and Islamic theology has a significant difference with the general attitude of the people of Banten and its surroundings. An important implication of the results of this study is that several themes on history, Islamic social and political thought, as well as the science of monotheism and the science of kalam need to be reviewed, enriched by references, and further enrich the sources of religious thought.
\end{abstract}

Keywords: Moderate; Public college; Religion lecturer; Religious paradigm

\begin{abstract}
Abstrak
Penelitian ini bertujuan untuk menjelaskan paradigma keagamaan dosen mata kuliah pendidikan agama Islam pada Universitas Tirtayasa Banten, dengan menggunakan pendekatan kualitatif. Penelitian dilakukan pada bulan April hingga Juni tahun 2021. Teknik pengumpulan data menggunakan wawancara, dan konten analisis. Informan yang terlibat adalah seluruh dosen pendidikan agama Islam. Penelitian ini menemukan adanya variasi paradigma keagamaan, latar belakang pendidikan dan minat keilmuan, akses terhadap sumber dan bahan bacaan, serta corak keagamaan yang dianut. Buku yang digunakan mengandung problem akut terkait dengan masalah moderasi beragama. Bahasan tentang tema-tema tauhid dan teologi Islam memiliki perbedaan yang signifikan dengan anutan umum masyarakat Banten dan sekitarnya. Implikasi penting dari hasil kajian ini, beberapa tema tentang sejarah, pemikiran sosial dan politik Islam, serta ilmu tauhid dan ilmu kalam perlu dilakukan peninjauan ulang, pengayaan referensi, dan lebih memperkaya nuktahnuktah pemikiran keagamaan.
\end{abstract}

Kata kunci: Dosen agama; Moderat; Paradigma keagamaan; Perguruan tinggi umum 


\section{PENDAHULUAN}

Paradigma keagamaan adalah cara pandang yang didasarkan atas keyakinan keagamaan yang digunakan untuk menilai dunia dan alam sekitarnya (Wahyuddin et al., 2009; Chanifudin and Nuriyati, 2020). Cara pandang ini merupakan perspektif umum untuk menjabarkan berbagai macam permasalahan dunia nyata yang sangat kompleks. Maka, untuk kepentingan kajian ini, paradigma keagamaan meliputi moderat, radikal, dan liberal (M. Syamsul Huda and Djalal, 2020; Faqihuddin, 2021). Moderat (Latin: moderatio) dipahami sebagai ke-sedang-an, tidak berlebihan, dan tidak kekurangan, alias seimbang (Rohman, 2020; Naim, 2021; Singgih, Darmawan and dkk, 2021). Dengan demikian, moderat berarti pengurangan kekerasan, atau penghindaran keekstrem-an. Dalam Bahasa Arab, kata ini sepadan dengan wasath atau wasathiyah, yang berarti tengah-tengah, dan mengandung makna i'tidal (adil) dan tawazun (berimbang) (Hefni, 2020; Munir et al., 2020; Rizky and Syam, 2021).

Radikal dipahami sebagai upaya suatu kelompok agama tertentu untuk mendapatkan kekuasaan dan/atau mengubah bentuk kekuasaan suatu negara dengan cara kekerasan, serta menggunakan simbol dan/atau ajaran agama tertentu demi mencapai tujuan dan mendapatkan manfaat dari penggunaannya (Khamid, 2016; Natalia, 2016). Ada 4 ciri radikalisme dalam beragama, meliputi intoleran, fanatik, ekslusif, dan revolusioner (Wibowo, 2014; Jamil, 2017; Salim, Suryanto and Widodo, 2018). Seseorang juga dikatakan radikal ketika tidak dapat menghargai pendapat atau keyakinan orang lain. Bagi kelompok ini, hanya ajaran agamanya yang benar, sementara keyakinan lain dicap sebagai salah dan sesat. Selain itu, paradigma radikal juga ditunjukkan dengan sikap revolusioner yang menginginkan perubahan menyeluruh, dan dilakukan dengan cara kekerasan (Munir et al., 2020). Dalam realitas sosial dan historis, radikalisme keagamaan ini merupakan fenomena umum yang terjadi pada semua agama, seperti Yahudi, Islam, Kristen, Katolik, Hindu, dan Buddha (Abdullah, 2016; Qodir, 2018).

Kategori paradigmatik yang ketiga adalah liberal. Mengutip Judson, Zarkasi menyebut beberapa ciri liberal dalam beragama, yakni banyak mengingkari firman Tuhan, mengutuk berbagai kesalahan di zamannya, mengakui Tuhan hanya sebatas kepentingan kemanusiaan, tidak ada yang mutlak dan pasti tentang Tuhan, mempromosikan keraguan beragama, dan mendukung keyakinan keagamaan yang populer (seperti kelompok Penghayat, Syi'ah, Ahmadiyah, dan sebagainya) (Zarkasyi, 2010).

Lebih dari itu, paradigma liberal juga dikenal menentang teokrasi, yakni sistem kekuasaan yang didasarkan atas kitab suci (Hakim, 2011; Erowati, 2018). Kelompok ini juga tidak setuju dengan gagasan penyatuan agama dan negara, mendukung demokrasi sebagai mekanisme dalam sirkulasi elit politik atau pemerintahan, mendorong kesetaraan gender dan hak perempuan untuk aktif di ranah publik (Zubaedi, 2013; Erowati, 2018). Paradigma liberal dalam beragama juga tidak memposisikan non-Muslim sebagai warga negara kelas dua dalam konteks hak sipil berbangsa dan negara, serta menyerukan kebebasan berpikir atau membuka selebarlebarnya pintu ijtihad yang dipandang sebagai prasyarat bagi kemajuan peradaban (Kurzman, 2001).

Berdasarkan kerangka konsep di atas, kajian ini hendak melihat cara pandang dosen pendidikan agama terhadap doktrin, nilai, dan ajaran agama. Sebagai pengajar PAI di perguruan tinggi, dosen wajib menyusun program pembelajaran bagi mahasiswa sesuai dengan tujuan pendidikan agama, yakni membentuk generasi yang beriman dan bertakwa kepada Tuhan Yang Maha Esa, berakhlak mulia, membangun kedamaian dan kerukunan hubungan inter dan antar umat beragama, serta berkembangnya kemampuan peserta didik dalam memahami, menghayati, dan mengamalkan nilai-nilai agama. Karena itu, kajian terhadap bahan ajar yang telah disusun oleh para dosen PAI menarik dilakukan sebagai bagian dari penelitian Paradigma Kagamaan Dosen Pendidikan Agama di Perguruan Tinggi Umum.

\section{METODOLOGI}

Kajian tentang Paradigma Keagamaan Dosen Pendidikan Agama ini dilakukan terhadap buku Pendidikan Agama, baik sebagai 
bahan ajar maupun bahan diskusi. Tetapi analisis dibatasi hanya pada Buku PAI yang ditulis dan diterbitkan oleh dosen Pendidikan Agama Islam di Universitas Tirtayasa, Serang, Banten. Seperti akan dijelaskan, dosen PAI Untirta hingga saat ini telah menerbitkan sedikitnya 16 (enam belas) buku bahan ajar dan panduan perkuliahan untuk makasiswa di berbagai fakultas dan jurusan. Buku-buku itu ditulis secara kolektif melalui proses diskusi dan dialog panjang di antara dosen yang memiliki latar belakang dan minat keilmuan dalam studi Islam yang beragam. Di dalamnya tedapat magister pendidikan, pemerhati bidang tafsir dan hadits, aktivis sosial keagamaan, peminat bacaan-bacaan sejarah Islam. Selain itu ada pula dosen dengan latar belakang ilmu hukum, syari'ah, ushuluddin, ekonomi syariah, dan lain-lain. Kurang lebih, dalam keragaman minat akademik itulah buku-buku teks dan bacaan penunjang perkuliahan itu ditulis.

Penetapan terhadap isi buku sebagai moderat, radikal, atau liberal itu dilakukan melalui pendekatan analisis wacana atau discourse analysis. Apa yang disebut sebagai Analisis Wacana dalam kajian ini adalah suatu kajian atau analisis bahasa yang digunakan secara alamiah dalam bentuk tulisan terhadap para pengguna sebagai suatu elemen masyarakat. Kajian terhadap suatu wacana dapat dilakukan secara struktural dengan menghubungkan antara teks dan konteks, serta melihat suatu wacana secara fungsional dengan menganalisis tindakan yang dilakukan seseorang untuk tujuan tertentu guna memberikan makna kepada partisipan yang terlibat. Data yang digunakan dalam analisis ini terfokus pada konstruksi kewacanaan dalam bentuk teks tulis buku Pendidikan Agama Islam.

Sebagai sebuah pendekatan penelitian, menurut Ibnu Hamad, analisis wacana memiliki sejumlah metode analisis yang berawal dari teori social (Hamad, 2007). Penelitian ini menggunakan analisis wacana kritis, yakni pendekatan yang menekankan peran aktif wacana dalam membangun perubahan di dunia sosial, melalui penggunaan bahasa kongkret berdasarkan kesepakatan masyarakat. Hasil dari proses ini adalah bentuk wacana (naskah) berupa teks (wacana dalam wujud tulisan/grafis), talk (wacana dalam wujud ucapan), act (wacana dalam wujud tindakan), dan artifact (wacana dalam wujud jejak).

Pilihan terhadap "Analisis Wacana" sebagai pisau yang membedah paradigma keagamaan sebagaimana termuat dalam bububuku bahan ajar Pendidikan Agama Islam (PAI) karya para dosen di Untirta ini dinilai relevan, serta dapat memberikan makna yang lebih kuat terkait dengan kategorisasi paradigma keagamaan moderat, radikal, dan liberal seperti telah diurai di atas. Dengan tetap mengikuti Hamad (2007), sebuah wacana muncul dari proses konstruksi realitas oleh pelaku yang dimulai dengan adanya realitaas pertama berupa keadaan, benda, pikiran, orang, peristiwa, dan sebagainya. Secara umum, sistem komunikasi adalah faktor yang mempengaruhi sang pelaku dalam membuat wacana. Dalam sistem komunikasi yang bebas (libertarian), wacana yang terbentuk akan berbeda dalam sistem komunikasi yang terkekang (otoritarian). Secara lebih khusus, dinamika internal dan eksternal yang mengenai diri si pelaku konstruksi tentu saja sangat mempengaruhui proses konstruksi. Ini juga menunjukkan bahwa pembentukan wacana tidak berada dalam ruang hampa. Pengaruh itu bisa datang dari pribadi si pembuat dalam bentuk kepentingan idealis, ideologis, dan sebagainya, maupun dari kepentingan eksternal dari khalayak sasaran sebagai pasar, sponsor, dan sebagainya.

Untuk melakukan konstruksi realitas, lanjut Hamad, pelaku konstruksi memakai suatu strategi tertentu. Tidak terlepas dari pengaruh eksternal dan internal, strategi konstruksi ini mencakup pilihan bahasa, mulai dari kata hingga paragraf, pilihan fakta yang akan dimasukkan atau dikeluarkan dari wacana yang populer disebut strategi framing; dan pilihan teknik menampilkan wacana di depan public misalnya di halaman muka/dalam, di prime time/bukan atau taktik priming. Selanjutnya hasil dari proses ini adalah wacana (discourse) atau realitas yang dikonstruksikan berupa tulisan (teks), ucapan (talk), atau peninggalan (artifack). Oleh karena discourse yang terbentuk ini telah dipengaruhi oleh berbagai faktor, dapat dikatakan bahwa di balik wacana itu terdapat makna dan citra yang diinginkan serta kepentingan yang sedang diperjuangkan. 
Dalam konteks kajian ini, penulis mengambil analisis wacana paradigmatic (Hamad, 2007), yang memperhatikan tandatanda (sign) tertentu dalam sebuah wacana untuk menemukan makna keseluruhan. Dalam hal ini kajian terhadap buku PAI akan menggunakan bentuk analisis wacana sosial, yang menganalisis wacana dengan memakai satu atau lebih analisis wacana menggunakan perspektif teori tertentu dan menerapkan paradigma penelitian tertentu. Analisis di sini dibatasi pada level naskah dalam bentuk teks secara paradigmatis.

\section{HASIL DAN PEMBAHASAN}

\section{Selintas tentang Untirta dan PTU di Banten}

Pilihan terhadap Universitas Sultan Ageng Tirtayasa (Selanjutnya disebut Universitas Tirtayasa, atau disingkat Untirta), Serang, Banten, didasarkan atas kenyataan bahwa perguruan tinggi ini merupakan salah satu universitas umum negeri di Banten, selain UIN Sultan Maulana Hasanudin (SMH) di Serang, UIN Syarif Hidayatullah Jakarta di Ciputat, Universitas Terbuka di Pondokcabe, Tangerang Selatan, dan beberapa universitas umum lainnya. Selebihnya, terdapat cukup banyak perguruan tinggi swasta di berbagai kabupaten dan kota, seperti Universitas Pamulang (Tangerang Selatan), Universitas Muhammadiyah Tangerang (UMT, Kota Tangerang), Universitas Syekh Maulana Yusuf (Kota Tangerang), Universitas Serang Raya (Unsera, Kota Serang), dan Universitas Mathla'ul Anwar (UNMA) di Menes, Pandeglang, serta lebih dari 100 perguruan tinggi lainnya.

Untirta juga termasuk ke dalam universitas favorit di Banten, yang dipilih oleh segenap mahasiswa dari berbagai wilayah, termasuk provinsi lain di Indonesia. Berdiri pada tahun 1980-an, semula Untirta merupakan perguruan tinggi swasta yang didirikan oleh Yayasan Pendidikan Tirtayasa. Nama Tirtayasa diambil dari salah satu sultan Banten, yakni Sultan Ageng Tirtayasa, pewaris tahta ke-empat kesultanan Banten dengan nama asli Abul Fatih Abdul Fatah. Berdasarkan keputusan Mendikbud Nomor 0596/0/1984, status ketiga sekolah tinggi yang bergabung itu kemudian berubah, masing-masing menjadi Fakultas
Hukum, Fakultas Teknik, dan Fakultas Keguruan dan Ilmu Pendidikan (FKIP). Lima tahun kemudian, pada 1989, Untirta menambah 2 fakultas, yakni Fakultas Pertnian dan Fakultas Ekonomi.

Dalam pada itu, perubahan sosial politik yang terjadi di Indonesia telah pula mempengaruhi perubahan yang terjadi pada Untirta. Didasari oleh perkembangan Unitirta sebagai perguruan tinggi swasta yang kurang signifikan, telah mendorong pimpinan universitas dan para pimpinan fakultas serta pengurus Yayasan Pendidikan Tirtayasa, ditambah dukungan yang kuat dari para tokoh Banten untuk mengusulkan penegerian. Maka, atas usulan itu, pada 1999 keluarlah Kepres RI No 130 Thun 1999 tentang Persiapan Perguruan Tinggi Negeri Universitas Sultan Ageng Tirtayasa. Dua tahun kemudian, keluar pula Kepres No. 32 Tahun 2001 yang menyatakan Universitas Sultan Ageng Tirtayasa secara definitif menjadi universitas negeri. Sekitar 10 tahun kemudian, pada 2012, Untirta telah berhasil mengembangkan berbagai program pendidikan. Program pendidikan akademik terdiri atas Program Pendidikan Sarjana sebanyak 6 (enam) fakultas dan 1 program magister (Pascasarjana), meliputi: Fakultas Hukum, Fakultas Keguruan dan Ilmu Pendidikan, Fakultas Teknik, Fakultas Pertanian, Fakultas Ekonomi, Fakultas Ilmu Sosial dan Ilmu Politik, serta Pascasarjana. Selain itu, Untirta juga menyelenggarakan program vokasi dalam bentuk Diploma III, yaitu prodi akuntansi, pemasaran, perpajakan, keuangan dan perbankan. Ada pula prodi Teknik komputer dan multimedia. Kini, setelah berdiri FISIP dan Fakultas Kedokteran, Untirta memiliki 7 Fakultas dengan 64 program studi. Universitas terpavorit di Banten itu kini ditangani oleh 15 orang profesor, 223 doktor, 629 magister, dan 433 tenaga kependidikan lainnya.

Secara keseluruhan, data tahun 2021, jumlah mahasiswa Untirta tercatat sebanyak 8.123 orang yang tersebar di 7 (tujuh) Fakultas. Jumlah terbanyak ada di Fakultas Keguruan dan Ilmu Pendidikan, disusul Fakultas Hukum, Ekonomi, Fisip, Teknik, Pertanian, dan Kedokteran. Dari kategori anutan keagamaan, mahasiswa yang beragama Islam mencapai 
7.634 orang (lebih dari 97\%), disusul Kristen (290 orang), Katolik (185 orang), Hindu (9 orang), Buddha (5 orang), dan Konghucu (tidak ada).

\section{Profil Dosen Pendidikan Agama}

Di Untirta tidak hanya terdapat mahasiswa Muslim, tetapi juga, dalam jumlah yang cukup signifikan, ada pula mahasiswa yang beragama Kristen, Katolik, Hindu, dan Buddha. Hingga 2021, tidak terdapat mahasiswa beragama Konghucu. Maka, sesuai dengan aturan perundang-undangan, setiap mahasiswa yang memiliki keyakinan yang beragam itu, wajib mendapatkan pelajaran agama yang dianutnya, dan diampu oleh dosen dengan anutan keagamaan yang sama.

Demikianlah, berdasarkan data Pusat Unit Pelaksana Pengembangan Mata Kuliah Umum (UPP-MKU) termasuk yang membawahi Pendidikan Agama di Untirta terdapat 24 orang dosen pendidikan agama, masing-masing 21 orang dosen PAI, dan satu orang dosen Pendidikan Agama Katolik, satu orang Kristen, 1 orang dosen Hindu, dan 1 orang dosen Pendidikan Agama Buddha. Sementara dosen PA Konghucu tidak tersedia. Dengan data umum seperti ini, catatan secara khusus perlu diberikan terhadap dosen Pendidikan Agama Islam. Pada tahun 2021, dosen PAI terdiri atas 10 laki-laki dan 11 perempuan. 6 orang di antaranya telah berpendidikan S3, termasuk 2 orang perempuan. Sementara sisanya sebanyak 15 orang lulus S2 atau bergelar master. Belum ada seorang pun guru besar dari dosen PAI itu, karena tidak ada prodi itu di Untirta.

Selain dosen PAI, semua dosen pendidikan agama merupakan tenaga tidak tetap yang diambil dari Kementerian Agama. Dosen Pendidikan Agama Katolik (Drs. Osner Purba, MSi.), misalnya, saat ini menjabat sebagai Kepala Bidang Bimas Agama Katolik di Kanwil Kemenag Provinsi Banten. Osner telah menjadi dosen sejak Untirta masih merupakan perguruan tinggi swasta pada 1998. Sambil menjalankan tugas sebagai ASN, Osner yang mengikuti uji kompetensi sebagai pengajar melalui pendidikan Akta-4, kemudian memperoleh status sebagai dosen tetap di Untirta berdasarkan ketetapan Rektor saat itu. Hingga saat ini, ia telah mengabdi sebagai dosen Pendidikan Agama Katolik lebih dari 20 tahun, dengan jumlah honorarium sebanyak 800 ribu rupiah setiap semester yang dibayarkan setiap 6 (enam) bulan sekali. Menarik, bahwa dengan masa bakti selama itu ia juga tidak memiliki fasilitas perkantoran khusus, seperti ruang kerja, petugas administrasi, dan lain-lain. Setiap sebelum atau setelah mengajar ia cukup berbaur di ruangan dosen pendidikan agama, atau langsung kembali ke kantornya di Kementerian Agama.

Sementara untuk dosen agama Kristen (Benny Halim, R. Butar-Butar, dan Marlan Hutauruk) merupakan peendeta di salah satu gereja di Banten. Akan halnya dosen Pendidikan Agama Hindu (Aris Widodo, MPd.) dan Buddha (Sakiyo, MPd), masing-masing menjabat sebagai Penyuluh Agama Hindu di Kemenag Kota Serang dan Penyelenggara Bimas Agama Buddha di Kemenag Kab Tangerang. Seperti Osner, para dosen pendidikan agama dari Kristen, Hindu, dan Buddha pun ditetapkan sesuai dengan kebijakan perguruan tinggi, dan diambil melalui pengajuan dan permohonan dari lembaga keagamaan masing-masing. Dengan demikian, tidak ada satu pun dosen Pendidikan Agama non-Islam yang memiliki status sebagai pegawai tetap di Untirta, karena status kepegawaiannya secara tetap di Kementerian Agama atau menjadi rohaniawan di gereja.

Untuk mengoptimalkan layanan keagamaan, masing-masing dosen Pendidikan Agama tidak sekedar memberikan pelajaran di ruang kuliah, tetapi juga melalui bimbingan peribadatan di tempat ibadah masing-masing. Sebagai dosen Pendidikan Agama Katolik, Osner Purba, misalnya, mewajibkan mahasiswanya untuk mengikuti kebaktian di Gereja. Meski di luar sistem perkuliahan, bimbingan keagamaan ini diikuti dengan seksama oleh para mahasiswa, karena berimplikasi langsung terhadap nilai mata kuliah PAK. "Yang jarang datang kebaktian tidak mungkin memperoleh nilai A", katanya.

\section{Buku dan Bahan Ajar Pendidikan Agama Islam di Untirta}

Dalam dokumentasi Nanah Sujanah (sekretaris tim MKU PAI Untirta) yang berhasil ditelusuri, Tim Dosen Mata Kuliah Pendidikan 
Agama Islam Untirta sedikitnya telah menerbitkan 16 buku PAI, baik sebagai bahan ajar, pengantar seminar mahasiswa, dan buku bacaan penunjang bagi pengembangan wawasan keagamaan. Buku-buku itu ditulis secara tematik berdasarkan problem keagamaan aktual secara periodik. Dari 16 buku, makalah ini akan menelusuri konten terhadap 6 di antaranya. Pilihan terhadap 6 buku yang diambil secara acak didasarkan atas beberapa pertimbangan. Pertama, dinamika historis mata kuliah PAI. Sebelum tahun 2017, kurikulum PAI di perguruan tinggi umum disusun berdasarkan kaitannya dengan fakultas dan konsentrasi keilmuan. Untuk mahasiswa Fakultas Hukum, misalnya, tema-tema keagamaan yang diberikan dikaitkan dengan masalah disiplin keilmuan hukum. Demikian pula halnya dengan fakultas dan jurusan yang lain, disesuaikan dengan persoalan keilmuan masing-masing. Ketetapan ini berubah dengan munculnya kebijakan baru sistem perkuliahan, di mana PAI diposisikan sebagai mata kuliah dasar umum yang diberikan secara seragam pada semua fakultas dan jurusan.

Kedua, tema-tema tulisan yang disusun. terdapat 2 kategori buku yang disusun oleh para dosen PAI di Untirta, yaitu buku bahan ajar yang disampaikan pada semester ganjil dan semester genap. Buku pertama disusun berdasarkan pedoman Mata Kuliah Dasar Umum (MKDU) PAI di Perguruan Tinggi; sementara buku kategori kedua disiapkan sebagai bahan diskusi mahasiswa yang ditulis berdasarkan aktualitas masalah sosial keagamaan pada tahun berjalan. Aktualitas masalah itu biasanya dipilih berdasarkan berita dan informasi di media massa, atau sesuai dengan masalah keagamaan yang tengah ditangani secara nasional

Ketiga, aktualitas tema keagamaan sesuai dengan konteks dan periode penyusunan. Di bawah asistensi Dr Fadlullah sebagai dosen senior, dosen-dosen PAI di Untirta secara periodik meninjau ulang buku-buku yang menjadi bahan ajar, dan menambahkan tema baru yang muncul pada tahun berjalan. Secara keseluruhan, selain bahan ajar yang didasarkan atas pedoman MKDU, buku-buku yang ditulis untuk bahan diskusi mahasiswa sepenuhnya mempertimbangkan aspek aktualitas ini.
Karena itu, pilihan secara acak terhadap 6 (enam) buku ini dapat merepresentasikan paradigma keagamaan dosen PAI di Untirta secara umum.

Sedikitnya Tim Dosen Mata Kuliah Pendidikan Agama Islam Untirta telah menerbitkan 16 (enam belas) buku sebagai bahan ajar PAI, meliputi: Religiositas dan Pembangunan Umat Islam, terbit tahun (2019); Islam Aplikatif (Pendidikan Agama Islam 1) (2016); Identitas Islam dalam Tamansari Kemajemukan Indonesia (2017); Mengenal Politik dan Ketatanegaraan Islam (Buku Ajar Seminar Agama) (2017); Khazanah Peradaban Islam Nusantara (2017), dan Dinamika Nalar Islami (2020). Selain itu, ada pula Islam Progresif, Horison Cakrawala Sistem Pendidikan Islam, Modul Materi Lingkar Studi Pekanan Mata Kuliah Pendidikan Agama Islam, Pembelajaran Transformatif Pendidikan Agama Islam untuk Perguruan Tinggi, dan Nilai-nilai Ekonomi dalam Perspektif $\mathrm{Al}$ Qur'an. Patut disayangkan, 5 (lima) buku lainnya tidak berhasil dilacak keberadaannya.

Menarik bahwa seluruh buku Pendidikan Agama Islam yang ditulis oleh dosen-dosen Untirta dilakukan secara kolektif. Tidak satu pun buku yang ditulis hanya oleh satu orang. Ini menunjukkan tingginya kebersamaan, kepedulian, dan komitmen bersama dalam membangun pembelajaran PAI yang baik dan ideal bagi kalangan mahasiswa di semua fakultas dan jurusan. Menarik pula bahwa bukubuku itu disusun berawal dari Kajian Pekanan yang dilaksanakan pada setiap hari kamis. Dalam diskusi mingguan ini masing-masing dosen secara bergiliran mempresentasikan judul dan rancangan penulisan dalam bentuk sistematika dan alur pikir yang akan ditulis. Disampaikan pula sumber referensi yang tersedia sebagai basis informasi keilmuan yang relevan.

Tentu ada pula proses penulisan yang sedikit "menyimpang" dari tahapan ini. Dari bab-bab yang muncul di berbagai buku, nampak ada beberapa tulisan yang terkesan pengulangan, tentu dengan sedikit polesan kata, perubahan kalimat, dan penyederhanaan bahasa. Tulisan tentang Tauhid, misalnya, dengan jelas menggambarkan adanya pengulangan dan penyederhanaan dari tulisan 
awal. Hal ini nampak dari sumber bacaan dan footnote yang nyaris sama. Pada tulisan yang lain, misalnya, penulis melakukan kajian spesifik terhadap surat al-Fatihah tetapi dalam perspektif tauhid. Hasilnya, penulis coba melakukan analisis dan menarik kesimpulan dengan paradigma tauhid yang telah ditulis sebelumnya pada buku yang lain. Selain itu, seperti umumnya terjadi pada penulisan buku yang dilakukan secara kolektif, ada pula dosendosen yang tidak terlibat dalam penulisan, tetapi tetap ingin dicantumkan namanya dalam tim penulis. Ini tentu tidak sekedar masalah terbatasnya keterampilan menulis, masalah senioritas dosen, adanya kejenuhan berpikir, dan kesibukan lain sehingga tidak memiliki waktu yang cukup untuk merenung dan menulis. Tetapi juga berkaitan dengan urusan pemenuhan administratif sebagai dosen bagi kepentingan naik pangkat atau perolehan insentif dan tunjangan kinerja.

Masalah lain yang sangat krusial dalam penulisan sebuah buku, termasuk di dalamnya buku bahan ajar, adalah soal referensi dan sumber bacaan. Kedalaman sebuah tulisan akan sangat tergantung pada kekayaan bahan bacaan yang menjadi sumbernya (Raco, 2018). Bahkan, bahan bacaan yang digunakan sebagai sumber penulisan dalam buku pendidikan agama untuk sebagian dapat menunjukkan paradigma keagamaan yang diusung seorang penulis. Oleh sebab itu, mengidentifikasi dan menganalisis sumber bacaan yang dipakai merupakan hal yang penting untuk melihat ke mana arah sebuah buku ditulis, dan dalam paradigma apa buku itu berada.

\section{Paradigma Keagamaan Bahan Ajar PAI}

\section{Religiositas dan Pembangunan Umat Islam}

Buku yang terbit pada 2019 ini disusun agar perkuliahan Pendidikan Agama Islam dapat disampaikan secara seragam oleh dosen, dan diterima oleh mahasiswa. Ditulis berdasarkan rujukan Al-Quran dan hadits yang secara khusus tercantum dalam kitab Bulugh alMaram ini ditulis agar mahasiswa memiliki 10 karakter dalam beragama, yakni salim alaqidah, shalih al-ibadah, matin al-khuluq, qawiyy al-jism, mutsaqqaf al-fikr, mujahadatun li nafsih, harits 'ala waqtih, munadzdzam-un fi syu'unihi, qadir-un 'ala al-kasb, dan nafi'un li-ghairihi. Sayangnya, Fadlullah sebagai penyunting buku ini tidak memberikan penjelasan lebih detil terhadap 10 point dari karakter yang disebutnya, serta tidak menyebutkan sumber referensinya.

Isi buku ini nampak lebih sederhana, dan umumnya membahas persoalan fikih. Diawali dengan artikel tentang model pembelajaran PAI, buku kemudian membahas soal Mengenal Din al-Islam, paradigma tauhid, fikih bersuci, fikih salat, fikih zakat dan keadilan sosial, fikih ramadan, fikih haji, dan masjid madani. Dengan kandungan seperti ini, Nampak isi buku tidak fokus pada satu titik permasalahan Islam, meski bab di dalamnya lebih banyak membahas masalah fikih ibadah.

Seperti pada buku lain yang ditulis oleh para dosen PAI Untirta, konsep tauhid di sini dikategorisasi ke dalam 3 (tiga) cabang, yakni rububiyah, uluhiyah, dan mulkiyah. Dalam konteks surat Al-Fatihah sebagai induk AlQuran, ketiga aspek tauhid itu dapat ditelusuri dari tiga hal berikut: Pertama, hukum yang mengatur alam semesta seluruhnya yang sepenuhnya berada dalam kekuasaan Tuhan, yang menjadi inti tauhid rububiyah; Kedua, hukum yang mengatur masyarakat manusia untuk menyembah hanya kepada Allah, serta taat dan patuh kepada syariat-Nya, dengan atau tanpa persetujuan manusia. Inilah yang menjadi inti tauhid uluhiyah; dan ketiga, hukum yang dibuat manusia dan berlaku untuk (mengatur) masyarakat manusia sendiri berdasarkan musyawarah sesuai maqashid al-syari'ah. Inilah yang menjadi inti tauhid mulkiyah. Kemudian ditegaskannya bahwa manusia diciptakan oleh Allah untuk melaksanakan mandatNya, sebagai 'abdullah sekaligus khalifatullah. Maka, setiap Muslim yang bertauhid senantiasa memperbaharui komitmen, bahwa "aku berbuat apa pun karena Allah, sesuai syariat Allah, dan sebagai bentuk pengabdian kepada Allah untuk memperoleh ridha-Nya. Menariknya, prinsip ini kemudian disebut sebagai “...deklarasi fundamental setiap muslim sebagai ummatan wasatho yang bertugas memimpin dunia." (hal. 53).

Selanjutnya diuraikan, dengan mengutip Ibn Taymiyah yang diambilnya dari buku Yusuf Qardhawi, bahwa Ilah adalah yang dipuja penuh kecintaan hati, tunduk kepadanya, 
merendahkan diri di hadapannya, takut dan mengharapkannya, kepadanya tempat berpasrah saat berada dalam kesulitan, berdoa dan bertawakal kepadanya untuk kemaslahatan diri, meminta perlindungan diri kepadanya, dan menimbulkan ketenangan saat mengingatnya dan terpaut cinta padanya. Pada titik ini kemudian disebutkan bahwa tuhan itu bisa berbentuk apa saja yang dipentingkan oleh manusia, seperti harta, tahta, dan popularitas. Karena itu, disadari atau tidak, manusia bisa terjerumus "mempertuhankan diri" dalam bentuk sifat ria, egoisme, takut dan bimbang, zalim, hasad, dan dengki. Kurang lebih, inilah logika syirik sebagai dosa terbesar dalam Islam.

Dalam koteks ini pula penulis bab ini menyebut peran kekhalifahan manusia mengelola bumi demi kemakmuran umat manusia hanya bisa dilakukan oleh orang yang beriman. Bahwa iman yang benar dapat mengantarkan manusia pada paradigma pembangunan yang benar, yakni mengelola sumberdaya alam sesuai hukum keseimbangan yang ditetapkan Allah, tidak mengeramatkan alam, tetapi juga tidak merusaknya. Sebaliknya dikatakan bahwa orang-orang musyrik yang mengeramatkan alam telah gagal memahami hukum-hukum Allah yang berlaku pada alam sebagaimana terlihat pada gejala alam tersebut. Pikiran mereka terbelenggu oleh tradisi leluhur, sehingga mereka tidak mampu berpikir kritis, logis dan koheren. Maka, dalam posisi ini, harkat dan martabat manusia melorot lebih rendah dari binatang. (hal. 58).

Uraian tentang prinsip Tauhid dalam surat Al-Fatihah kemudian bermuara pada titip principal, yakni rahmah sebagai inti tauhid rububiyah, ibadah sebagai inti tauhid uluhiyah, dan kedaulatan kekuasaan sebagai inti tauhid mulkiyah. (Lihat, hal. 58-70).

\section{Islam Aplikatif (Pendidikan Agama Islam 1)}

Islam Aplikatif merupakan salah satu buku yang paling awal terbit sebagai bahan ajar untuk mata kuliah PAI. Maka, bisa dimaklumi bila buku ini memperoleh sambutan serius dari rektor Untirta sebagaimana tercantum di buku. Inilah satu-satunya buku yang mencantumkan sambutan rektor, sementara buku-buku yang lain tidak. Dalam kata sambutan, rektor menyebut pentingnya pengembangan kesadaran keberagamaan dan membangun karakter Jawara melalui pendidikan agama. Apa yang disebutnya sebagai Jawara adalah karakter yang hendak dituju dari pendidikan agama, yakni jujur, adil, wibawa, amanah, religius, dan akuntabel. Spirit Jawara ini sepenuhnya merupakan cerminan dan implementasi dari visi kelembagaan Untirta, yakni maju, bermutu, berdaya saing, dan berkarakter dalam kebersamaan. Rektor juga menempatkan buku ini sebagai bagian dari usaha mengembangkan kemampuan dan membentuk watak serta peradaban bangsa yang bermartabat dalam rangka mencerdaskan bangsa, bertujuan untuk berkembangnya potensi peserta didik agar menjadi manusia yang beriman dan bertakwa kepada Tuhan Yang Maha Esa, berakhlak mulia, sehat, berilmu, cakap, kreatif, mandiri, dan menjadi warga negara yang demokratis serta bertanggung jawab.

Secara sistematis buku ini mengupas 12 masalah dalam 12 bab, meliputi Konsep Alquran tentang manusia, yang meliputi 4 bahasan utama, yakni proses penciptaan manusia, istilah-istilah manusia dalam al-Quran, peran dan tugas manusia, serta karakteristik manusia. Pada bab 2 dikupas tentang Din al-Islam, dengan 6 su bab yang terjalin secara berkelindan, yakni: pengertian Din al-Islam, metode mempelajari Islam, unsur-unsur Din alIslam, karakteristik Din al-Islam, sistem ajaran Islam, dan eksistensi Din al-Islam.

Sementara itu, dalam bab III buku ini mengupas secara khusus tema kepribadian yang dicintai Allah, yakni Muslim, Mukmin, dan Muhsin. Bahasan kemudian beralih ke masalah sumber nilai Islam yang dikupas dalam bab IV. Uraian tentang ini meliputi Al-Quran, AlSunnah dan Ijtihad. Kupasan ini menarik, karena penulis tidak menyebutkan Ijma dan qiyas sebagai sumber nilai sebagaimana umum dipahami oleh pemahaman mainstream umat Islam di Indonesia. Bersama dengan istihsan, mashalih al-mursalah, istishab, urf, dzari'ah, madzhab shahabi, syar'un man qablana, dan ta'arud al-dilalah, ijma' dan qiyas diposisikan sebagai bagian dari metode ijtihad. Dengan memeriksa sumber referensi yang dipakai, nampak bahwa penulis bab ini menyandarkan basis akademiknya pada buku "Rekonstruksi Sejarah Al-Quran'karya Taufik Adnan Amal; 
buku "Ensiklopedi Hukum Islam" yang dieditori oleh Abdul Aziz Dahlan (sic!), Syeikh Mahmoud Syaltut dalam "Islam Aqidah wa Syari'ah", Syekh Yusuf Qardhawi (Kayfa Nata 'ammalu ma'a al-Qur'an; dan Al-Ijtihad fi al-Syari'ah al-Islamiyah); Nasrun Husein (Ushul Fikih 1), dan Fathurrahman (Ikhtisar Musthahul Hadits).

Menarik bahwa ketika membahas masalah Tauhid dalam bab $\mathrm{V}$, buku ini menyandarkan pendapatnya pada pemikiran Muhammad ibn Abdul Wahab dan Ibn Taymiyah (Majmu'ah al-Tawhid), Yusuf Qardhawi (Tauhid dan Fenomena Kemusyrikan, Pustaka Darul Hikmah, Bima), Muhammad Imaduddin Abdulrahim (Kuliah Tauhid), dan Ismail Raji al-Faruqi (Tauhid Dasar Peradaban Islam). Dalam bahasan ini penulis mengupas 3 hal utama, yakni wahdaniyat Allah, dzat Asma, dan Sifat Allah, serta konsekuensi bertauhid. Seperti dipahami secara umum, bahasan tentang Wahdaniyat Allah membahas secara cukup komprehensif tentang 3 (tiga) doktrin tauhid, yakni rububiyah, uluhiyah, dan mulkiyah.

Apa yang disebut sebagai tauhid rububiyah adalah keyakinan yang berintikan pada penegasan atas ke-Esa-an Allah dalam af'al-nya (perbuatanNya) dalam penciptaan dan pemeliharaan alam semesta. Dalam mencipta Allah tidak mempunyai sekutu dan tidak ada penentang terhadap kekuasaan-Nya. Tidak ada kehendak makhluk yang menentang atau mempengaruhi terhadap Sang Pencipta. Doktrin tentang rububiyah ini, menurut sang penulis, secara filosofis dapat menjadi landasan bagi kosmologi Islam, yakni pandangan umum tentang realitas, kebenaran, ruang, waktu, dunia, dan sejarah. Karena itu dengan mengutip Al-Faruqi, sebagai pandangan dunia, tauhid rububiyah akan masuk pada prinsip dualitas (hubungan antara khalik dan makhluk), ideasionalitas (bahwa sttuktur realitas alam semesta bersifat ideasional), dan teleologis (bertujuan dan terencana). Sementara itu, tauhid uluhiyah berintikan pada penegasan atas keEsa-an Allah dalam dzat-Nya atau ketuhananNya dan dalam beribadah kepada-Nya, seperti dalam doa, nadzar, korban, berharap (raja'), takut (khawf), dan tawakkal. Prinsip wahdaniyah dalam dimensi uluhiyah ini menuntut dua masalah prinsip. Yakni tidak menyembah dan meminta pertolongan kepada selain Allah dan tidak mengakui ketuhanan selain Allah; serta menyembah Allah berdasarkan pada apa yang telah disyariatkanNya melalui teladan Rasul. Sedangkan Tauhid Mulkiyah berintikan pada ke-Esa-an Allah dalam kekuasaan dan hukumnya. Bahwa seorang yang beriman bertekad untuk senantiasa menyelaraskan segala gerak langkah dan keinginannya sesuai dengan kehendak Allah sebagaimana termaktub dalam Al-Quran. Dari ketiga dimensi tauhid ini, muncul pula implikasi bagi yang menolaknya, yakni syirik rububiyah, syirik mulkiyah, dan syirik uluhiyah (hal. 95).

Implikasi doktrinal dari ketigas aspek tauhid ini adalah adanya dojtrin tentang zat, asma, dan sifat. Dikatakan, bahwa mengenai sifat-sifat Allah, Ahl al-Sunnah wa al-jamaah sejak dulu hingga sekarang berpandangan bahwa tidak diperkenankan mensifati Allah dengan sesuatuyang Allah dan Rasul-Nya tidak menetapkan demikian, Dengan kata lain, sambil mengutip karya Muhammad ibn Abd AlWahhab dan Ibn Taymiyah, Allah mesti disifati dengan apa saja yang disifatkannya kepada diriNya sendiri, serta disifatkan oleh Rasul-Nya, tanpa melampaui Al-Quran dan Hadits, sehingga tidak terjebak ke dalam tajassim dan tasyabbuh; dan pada saat yang sama dapat mensucikan Allah (tanzih) dari sifat kemakhlukan, tanpa menafikan sifat Allah (ta'thil).

Menurut buku PAI Islam Aplikatif ini, asma' Allah yang indah sebagai bagian dari kepercayaan tauhid merupakan landasan etik umat Islam. Setiap Muslim bukan hanya perlu tahu, tetapi juha harus berhias akhlak dengan akhlak Allah sebagaimana tergambar dalam Asma'-Nya.

Dalam pada itu, pada bahasan berikutnya di bab VI, dikupas tentang ibadah ke dalam 4 (empat) sub-bah, yakni pengertian ibadah, jeni ibadah, hikmah ibadah mahdhah, dan syaratsyarat diterimanya ibadah. Kemudian bahasan dilanjut ke bab VII yang mengupas tentang fungsi salat dalam pembinaan akhlak, dengan 2 (dua) bahasan utama, yakni khusyu dalam salat, dan nilai-nilai aplikatif salat setelah salat. Pada bab VIII, kupasan beralih ke masalah zakat. Bab 
ini menguraikan 7 sub-bab, yakni pekertian zakat, prinsip-prinsip zakat, harta yang wajib dizakatkan berikut nishab dan kadar zakatnya, orang yang haram menerima zakat, manajemen pengelolaan zakat, serta implikasi zakat.

Bab berikutnya bicara tentang puasa, dengan judul yang cukup menggelitik: Training On dan Off Syahwat melalui Shaum. Bahasan ini mengupas 2 masalah pokok, yakni tentang jasmani dan ruhani manusia, serta pengendalian jasmani dan ruhani dalam shaum. Melengkapi bahasan tentang rukun Islam, pada bab $\mathrm{X}$ dibahas soal pokok-pokok ibadah haji yang membahas tentang definisi haji, syariat haji, dan kreteria haji. Bahasan lebih rinci nampak pada kreteria haji yang mengupas tentang syarat wajib haji, akhlak yang harus dimiliki oleh calon dan jamaah haji, larangan dalam beribadah haji dan umrah, rukun haji, wajib haji, sunnah-sunnah dalam haji, cara berhaji (tamattu, ifrad, dan qiran), badal haji, dan tentang hikmah ibadah haji.

Sementara dalam bab XI dan XII bahasan melebar ke masalah lain, yakni masyarakat madani dan kerukunan antar umat beragama, serta bahasan tentang akhlak dan tasawuf. Menarik bahwa bahasan tentang masyarakat madani dan kerukunan dikupas ke dalam 5 (lima) sub utama, yakni konsep masyarakat madani, karakteristik masyarakat madani, peranan umat Islam dalam membangun masyarakat madani, membangun masyarakat madani berbasis kearifan lokal, serta masalah kerukunan umat beragama.

\section{Identitas Islam dalam Tamansari Kemajemukan Indonesia}

Pada 2017 Tim Dosen PAI Untirta menerbitkan buku dengan judul menarik: Identitas Islam dalam Tamansari Kemajemukan Indonesia. Buku yang ditulis secara kolektif oleh 17 orang dosen ini dibangun di atas asumsi bahwa Pancasila dan UUD 1945 sebagai raga dari visi Islam rahmatan lil-'alamin. Bahkan, menurut sang koordinator, pemikiran yang tertulis dalam buku ini secara keseluruhan merupakan pengenalan identitas Islam dalam konteks keindonesiaan.

Secara keseluruhan buku ini memuat 13 bab, meliputi mengenal Islam, memurnikan tauhid, kembali ke Al-Quran dan as-Sunnah, keharusan berijtihad, jangan pisahkan salat dan zakat, iptek berbasis peradaban Islam, kepribadian Muslim, kerukunan antar umat beragama, dari pluralisme agama ke pluralisme hukum, politik dan pemerintahan dalam Islam, Islam dan ekonomi Pancasila, etika sosial dalam perspektif puasa dan haji, serta etika lingkungan.

Meski dalam pola ungkap dan struktur penulisan yang sedikit berbeda, bab II yang membahas tentang Memurnikan Tauhid, memiliki kesamaan nafas dan spirit dengan tulisan sejenis yang dimuat pada buku yang lain (Lihat, misalnya, Religiositas dan Pembangunan Umat Islam, hal. 51-76; Islam Aplikatif, hal. 85-96). Dapat diduga, penulisan dalam bab-bab tentang tauhid ini dilakukan oleh orang yang sama. Hal ini dapat ditelusuri dari sumber referensi yang digunakan, yang umumnya diambil dari sumber yang sama.

Bab lain yang menggelitik untuk dibaca adalah bahasan tentang Kepribadian Muslim (Bab VII). Secara ringkas, misalnya, bab ini mengupas tentang 10 (sepuluh) karakter Muslim. Yakni salimul aqidah (akidah yang bersih), shahih al-ibadah (ibadah yang benar), matin al-khuluq (akhlak yang kokoh), qawiyy al-jism (fisik yang kuat dan daya tahan tubuh yang kokoh), mutsaqqaf al-fikr (pemikiran yang mendalam, wawasan keilmuan yang luas), muijahadatun li-nafsihi (berjuang menahan hawa nafsu), haritsun 'ala waqtihi (mengelola waktu dengan memanfaatkan 5 perkara sebelum 5 perkara), munadzdzamun fi syu'unihi (teratur dalam suatu urusan), qadirun 'ala al-kasbi (mandiri secara ekonomi), dan nafi'un lighayrihi (bermanfaat bagi orang lain). Aspekaspek inilah yang dikutip secara selintas oleh editor dalam pengantar yang ditulisnya pada buku Religiositas dan Pembangunan Umat Islam.

\section{Mengenal Politik dan Ketatanegaraan Islam (Buku Ajar Seminar Agama)}

Secara tematik, buku Mengenal Politik dan Ketatanegaraan Islam yang terbit pada 2017 nampak lebih baik, runtut, dan bernas. Masingmasing bab terjalin secara berkelindan, tanpa "dijeda" oleh tema lain yang dipaksakan untuk masuk. Ini dapat dipahami, karen buku ini hadir sebagai bahan kuliah bagi mahasiswa Fakultas 
Ilmu Sosial dan Ilmu Politik (FISIP). Karena itu, tujuan penulisan buku ini juga jelas dan spesifik, yakni: 1) agar mahasiswa mengenal konsep politik Islam; 2) agar mahasiswa dapat memahami sejarah politik Islam dari zaman Rasulullah hingga masa al-khulafa al-rasyidun; dan 3) agar mahasiswa manjadi insan politik yang beriman, berilmu, dan berakhlakul karimah, sehingga konsep "Insan Kamil" dapat terwujud dalam kehidupan politik di Indonesia.

Secara substansi, buku ini dapat dikatakan "sensitif" karena mengupas masalah politik dan pemerintahan dalam Islam, yang dalam hal-hal tertentu dapat terpeleset ke dalam penghadapat secara kritis dengan sistem pemerintahan di Indonesia yang berdasarkan Pancasila. Apa yang disebut sebagai politik Islam dalam buku ini adalah "...suatu cara untuk mempengaruhi dan mengatur anggota masyarakat, agar berperilaku sesuai dengan ajaran Allah dan Sunnah Rasul-Nya." (hal. 2). Karena itu, dalam konsep Islam seperti disebut buku ini, kekuasaan tertinggi adalah Allah SWT, dan ekspresi kekuasaan dan kehendak Allah tertuang dalam Al-Quran dan Sunnah rasul. "Oleh karena itu penguasa tidaklah memiliki kekuasaan mutlak, ia hanyalah wakil (khalifah) Allah di muka bumi yang berfungsi membumikan sifat-sifat Allah dalam kehidupan nyata." Dengan begitu, maka tujuan politik dalam Islam adalah: 1) mengatur peraturan dan perundang-undangan negara sebagai pedoman dan landasan idiil dalam mewujudkan kemaslahatan umat; 2) pengorganisasian dan pengaturan untuk mewujudkan kemaslahatan; serta 3) mengatur hubungan antara pengusaha dan rakyat serta hak dan kewajiban masingmasing dalam usaha mencapai tujuan negara. (hal. 2-3).

Hal lain yang menarik dikupas dari buku ini adalah bahasannya tentang system pemerintahan dalam kepemimpinan Islam (Hal. 164-171). Dikatakan, bahwa sistem pemerintahan Islam bukan monarki, bukan republik, bukan kekaisaran, dan bukan federasi. Bukan monarki, karena "sistem pemerintahan Islam tidak mengenal sistem waris, namun pemerintahan akan dipegang oleh orang yang dibaiat oleh umat dengan penuh ridha dan kebebasan memilih. Bukan republik, karena system pemerintahan Islam berdiri di atas pilar akidah Islam serta hukum-hukum syara' di mana kedaulatan berada di tangan syara', bukan di tangan umat. Dalam hal ini baik umat maupun khalifah tidak berhak membuat aturan sendiri, karena yang membuat aturan adalah Allah semata. Bukan kekaisaran, bahkan kekaisaran amat jauh dari ajaran Islam, karena tidak menganggap sama antara ras satu dengan yang lain dalam hal pemberlakuan hukum di dalam wilayah kekaisaran. Bahwa tuntutan Islam dalam bidang pemerintahan adalah menganggap sama antara rakyat yang satu dengan yang lain dalam wilayah negara, menolak ikatan kesukuan, dan memberikan hak serta kewajiban kepada Non-Muslim yang memiliki kerarganegaraan. Bahkan, Islam juga menolak federasi yang membagi wilayah dalam otonominya sendiri yang menyatu dalam pemerintahan umum; sebab sistem pemerintahan Islam merupakan sistem kesatuan yang mencakup seluruh negeri secara utuh dan menyeluruh (Hidayatullah, 2017; Arobi, 2020).

Bahasan yang "serba-bukan" ini menarik dilihat, bukan hanya karena tidak tersedianya referensi bagi penguatan data ilmiah dan sumber akademik, tetapi juga sama sekali tidak didasarkan atas bukti historis dan fakta sejarah yang dapat memperkuatnya. Bahasan tentang ini sepenuhnya hanya bersifat wacana yang mungkin menarik didiskusikan, tetapi salam sekali tidak didasarkan atas bukti dan data yang dapat dipertanggung jawabkan.

\section{Dinamika Nalar Islami}

Dinamika Nalar Islami oleh penyuntingnya didaku menyajikan berbagai problem kontemporer di bidang fikih Islam dan menawarkan solusi berdasarkan sumber ajaran Islam serta nalar yang tajam secara moderat (wasathiyah). Dikatakan, bahwa Islam sebagai agama rahmatan lil-'alamin memiliki universalitas dan fleksibilitas selaras dengan perkembangan zaman dan tempat, berlaku untuk semua generasi, dan selalu aktual. Begitu pun dengan kemukjizatan dan otentisitas $\mathrm{Al}$ Quran menjamin relevansinya dengan dinamika zaman, senantiasa menjadi dasar salam menjawab persoalan yang berkembang seiring dengan dinamika perkembangan zaman. Sementara daya nalar kreatif mengasah pola pikir, meningkatkan kecerdasan dan sensitivitas daya amanisis, semangat perubahan, dan 
menjadi problem solver dalam menghadapi masalah yang kompleks sekalipun.

Dikatakan pula dalam pengantar, bahwa nalar merupakan sendi Susila, etika, dan moral. Nalar berperan sebagai instrumen bagi individu dan masyarakat, karena bernalar berarti sama dengan bersikap rasional, menggunakan kecerdasan untuk menentukan tinsakan terbaik dalam suatu keadaan. Secara spesifik buku ini disebut hadir untuk mempermudah mahasiswa dalam mata kuliat PAI, dan "menjadi landassan pembentukan sikap yang moderat dan konservatif, serta mendudukkan persoalan secara rasional dan proporsional."

Di atas harapan "nalar Islami" itulah, buku ini kemudian hadir dengan 8 (delapan) bab, masing-masing dengan tema tersendiri, meliputi Fikih Ikhtilaf, Fikih Aulawiyah: skala prioritas dalam Fikih Islam, Fikih Perempuan (Pendidikan Reproduksi), Fikih Munakahat: Poligami, Mut'ah dan Milkul Yamin, Fikih Siyasah: Suksesi Kepemimpinan dalam Sistem Politik Islam, Wakaf Shal dalam Wacana Fikih, Iptek dan Seni dalam Islam, serta Seni Budaya dalam Relasi Tasawuf.

\section{Khazanah Peradaban Islam Nusantara}

Seperti buku-buku lainnya, Khazanah Peradaban Islam Nusantara ditulis secara "berjamaah" oleh dosen PAI Untirta dari berbagai fakultas. Di bawah editor Fadlullah, buku dengan judul cukup menggelitik ini semula merupakan kumpulan tulisan dan hasil diskusi dosen PAI, yang berusaha menghadirkan Islam sebagai kelengkapan ideologis dan norma yang menjiwai kehidupan bermasyarakat dan bernegara. Dalam buku ini dibahas berbagai masalah sosial keagamaan, mulai dari pendekatan normatif hingga pendekatan sejarah. Tema yang dibahas pun cukup beragam, mulai dari isyu pluralisme, sosial budaya, pendidikan, hukum dan HAM.

Seperti nampak dari daftar isi. buku ini terbagi ke dalam 12 bab, mulai dari pembahasan tentang pendekatan studi Islam, Restorasi Indonesia versi Islam, Islam dan Pluralitas Bangsa Indonesia, Islam dalam konteks budaya Nusantara, Pendidikan Islam dalam sistem pendidikan nasional, Islam dan ketatanegaraan Indonesia, Hukum Islam, HAM dan Pembinaan Hukum Nasional, Islam Koperasi dan
Pembangunan ekonomi Kerakyatan, Bank dan Lembaga Keuangan Syariah, Tasawuf dan Karakter bangsa, Iptek dan Peran Kekhalifahan Alam Semesta, serta Islam, Etika Lingkungan dan Pembangunan Berkelanjutan. Kecuali beberapa tulisan seperti Islam dan pluralitas bangsa Indonesia serta Islam dalam konteks budaya Nusantara, rasanya judul buku ini secara tematik tidak sepenuhnya bersinggungan dengan masalah "khazanah peradaban Islam Nusantara.

\section{Pendidikan Agama dengan Ragam Paradigma}

Enam buku di atas memberikan gambaran yang menarik, tentang adanya ragam paradigma keagamaan dosen Pendidikan Agama Islam di Unirta, Serang, Banten. Keragaman paradigma itu tentu dilatarbelakangi oleh berbagai hal, seperti pendidikan, pengalaman keagamaan, aktivitas sosial keagamaan, sumber referensi yang dibaca, dan bahkan latar belakang sosiokultural yang membesarkannya. Meski demikian, aneka ragam paradigmatik dalam pemahaman keagamaan itu tidak sampai "terjatuh" pada pemikiran radikal dan ekstrem.

Dosen PAI secara keseluruhan memiliki kecenderungan yang terbuka terhadap perbedaan. Sepertinya masing-masing dosen memiliki kecenderungan akademik tertentu dalam memahami Islam, yang didasarkan pada aspek keislaman yang lebih diminati. Hal ini nampak dari keseragaman dan kedekatan tema yang diambil oleh masing-masing ketika hendak menulis. Tema tentang aspek teologi dalam Islam, misalnya, nampak ditulis oleh satu orang yang sama pada setiap buku yang diterbitkan. Ini dapat ditelusuri dari kesamaan referensi yang menjadi basis akademik dalam menguraikan dan membahas suatu masalah keagamaan.

Untuk melihat lebih jauh keragaman paradigma keagamaan itu, analisis ini akan melihat dari perspektif analisis wacana terhadap 3 hal pokok, yakni judul buku, tema-tema tulisan pada masing-masing bab, serta sumber referensi yang digunakan.

\section{Judul buku}

Seperti telah disebutkan, sedikitnya terdapat 16 buku buah karya kolektif para dosen 
di Untirta. Dari jumlah itu, saya berhasil menemukan 11 judul buku, yang 6 di antaranya dipilih secara acak sebagai objek kajian dalam penelitian ini. Ke-11 judul buku itu adalah Religiositas dan Pembangunan Umat Islam; Islam Aplikatif (Pendidikan Agama Islam 1); Identitas Islam dalam Tamansari Kemajemukan Indonesia; Mengenal Politik dan Ketatanegaraan Islam (Buku Ajar Seminar Agama); Khazanah Peradaban Islam Nusantara; Dinamika Nalar Islami; Islam Progresif, Horison Cakrawala Sistem Pendidikan Islam, Modul Materi Lingkar Studi Pekanan Mata Kuliah Pendidikan Agama Islam, Pembelajaran Transformatif Pendidikan Agama Islam untuk Perguruan Tinggi, dan Nilai-nilai Ekonomi dalam Perspektif Al-Qur'an.

Dari sisi judul, nampak ada beberapa buku yang terkesan "sensitif", yakni Mengenal Politik dan Ketatanegaraan Islam, serta Nilainilai Ekonomi dalam Perspektif Al-Qur'an. Buku pertama dipandang sensitif karena beberapa alasan: 1) beragamnya pemahaman umat terhadap sistem politik dan ketatanegaraan dalam Islam; 2) bahasan tentang ini acapkali bersinggungan secara politik dan ideologis dengan identitas keindonesiaan yang berasaskan Pancasila dan UUD 1945; 3) adanya sejarah kelam politik di Indonesia, terutama menyangkut pergulatan politik dan ideologi kenegaraan; 4) adanya pihak yang memandang perbedaan secara diametral antara Islam dan Pancasila; dan 5) munculnya "separatisme politik" dalam sepanjang sejarah Indonesia hingga hari ini, sampai munculnya "radikalisme politik" yang hendak memaksakan diberlakukannya Islam sebagai ideologi negara.

Selain itu, tema tentang Islam dan politik ini seringkali terjebak ke dalam "mitos" negara Islam yang seringkali tidak memiliki pijakan historis yang kuat. Tidak terkecuali dengan buku ini. Pada bab tentang Sistem Pemerintahan dalam Kepemimpinan, misalnya, dikatakan bahwa sistem pemerintahan Islam bukan monarki, bukan republik, bukan kekaisaran, dan bukan federasi. Bukan monarki, karena sistem pemerintahan Islam tidak mengenal sistem waris, namun pemerintahan akan dipegang oleh orang yang dibaiat oleh umat dengan penuh ridha dan kebebasan memilih. Bukan republik, karena sistem pemerintahan Islam berdiri di atas pilar akidah Islam serta hukum-hukum syara' dimana kedaulatan berada di tangan syara', bukan di tangan umat. Dalam hal ini baik umat maupun khalifah tidak berhak membuat aturan sendiri, karena yang membuat aturan adalah Allah semata. Bukan kekaisaran, bahkan kekaisaran amat jauh dari ajaran Islam, karena tidak menganggap sama antara ras satu dengan yang lain dalam hal pemberlakuan hukum di dalam wilayah kekaisaran. Bahkan, Islam juga menolak federasi yang membagi wilayah dalam otonominya sendiri yang menyatu dalam pemerintahan umum; sebab sistem pemerintahan Islam merupakan sistem kesatuan yang mencakup seluruh negeri secara utuh dan menyeluruh. Secara akademik narasi pada bab ini sepenuhnya problematik, karena tidak menjelaskan sistem Islam itu sendiri secara jelas, serta tidak mendapatkan basis historisnya secara kuat. Padahal banyak buku yang bisa dibaca, agar tidak terjebak pada "halusinasi politik" yang tidak perlu.

\section{Sumber Referensi}

Secara kategoris sumber referensi keagamaan sebagai basis hadirnya buku PAI di Untirta dapat dibagi ke dalam bahasa, bidang akademik, asal penulis, masa terbit, dan corak naskah. Karena itu, kitab suci (Al-Quran dan Hadits tidak dimasukkan ke dalam analisis referensi, kecuali bila terkait dengan pilihan ayat dan tafsir terhadap teks. Analisis terhadap sumber referensi ini penting dilakukan, untuk melihat dan mengetahui jenis bacaan dan sumber informasi keagamaan para penulis.

Cukup menggembirakan, sebagian dosen PAI di Untirta memiliki akses yang bagus terhadap karya-karya klasik, serta dengan sumber bacaan yang cukup luas. Karya-karya klasik itu umumnya merupakan "buku daras" yang menjadi bacaan utama di kalangan ulama di pondok pesantren, serta para dosen dan cendekiawan Muslim di perguruan tinggi. Dalam profil dosen PAI di Untirta, memang terdapat beberapa orang yang sempat studi ti Timur Tengah dan Al-Azhar Mesir. Sebagian lainnya lulus di SI dan S2 seta S-3 secara beragam di berbagai IAIN dan UIN di Serang, Jakarta, Bandung, dan Surabaya dengan berbagai jurusan dan konsentrasi keilmuan. Minat untuk membaca karya-karya klasik yang ditulis dalam bahasa Arab juga cukup tinggi di 
kalangan dosen lainnya. Ketersediaan berbagai buku dan kitab terjemahan saat ini cukup membantu mereka untuk membaca dan memahami isinya. Itu pula sebabnya, bukubuku dan kitab itu menjadi rujukan umum dalam menyusun buku dan menyiapkan bahan kuliah.

Berdasarkan serangkaian buku yang digunakan, tidak banyak secara spesifik membahas masalah teori dan metodologi. Hampir tidak ada dosen yang memiliki basis ilmu sosial yang kuat, seperti nampak dari nyaris tidak adanya karya-karya sosiolog dan antropolog yang dibaca dan menjadi rujukan. Penulis bahkan secara terbatas hanya mengutip buku karya Soerjono Soekanto, Sosiologi Suatu Pengantar, tetapi tidak satu pun ditemukan nama-nama seperti Peter L Berger, Max Weber, Talcott Parson, Emile Durkheim, Clifford Geertz, dan lain-lain. Bahasan yang cukup luas menjangkau berbagai masalah keagamaan kontemporer, rasanya hampir tidak mungkin referensi karya-karya itu dapat diabaikan. Ini mengindikasikan dengan jelas adanya keterbatasan metodologis di kalangan dosen PAI di Untirta.

Meski dengan referensi yang kaya, keterbatasan teorerik dan metodologis akan dengan sangat mudah bagi seseorang untuk terjatuh pada simplifikasi yang berlebihan, pembacaan yang tidak kritis terhadap sumber, terta terjebak pada kesimpulan-kesimpulan prailmiah yang tidak berdasar. Tulisan tentang tauhid dalam beberapa buku teks serta kajian tentang politik dan pemerintahan dalam Islam merupakan contoh yang gambling tentang jebakan pra-ilmiah serta alpanya daya kritik penulis terhadap teks. Atau, jangan-jangan berbagai buku yang dijejer dalam sumber bacaan itu hanya ditempel tanpa dibaca secara serius, untuk menghasilkan kesan "ilmiah". Sementara penulisannya sendiri dilakukan sempir secara sambil lalu, tanpa penelusuran sumber sebagaimana mustinya untuk sebuah karya ilmiah.

\section{Tema dan Wacana}

Pada bagian ini hendak dilihat relevansi tema-tema itu dalam konteks tujuan perkuliahan Pendidikan Agama sesuai dengan UU No. 12 Tahun 2012 tentang Perguruan Tinggi. Di sini hendak dilihat pula relevansi materi dan substansi PAI dengan konteks sosial keagamaan masyarakat di Indonesia, terlebih Banten yang dikenal kental dengan nuansa Islami, tempat di mana kampus Untirta berada. Lebih dari itu, penting pula dilihat, apakah tema-tema dan wacana yang dibangun dalam buku-buku PAI di Untirta memiliki kesesuaian dengan kebutuhan informasi keagamaan mahasiswa. Atau, apakah materi-materi dan bahasan itu selaras dengan tradisi dan kultur keagamaan masyarakat di lingkungan para mahasiswa.

Pada pasal 5 poin (a) disebutkan bahwa tujuan pendidikan nasional (tentu termasuk Pendidikan Agama Islam) adalah “...berkembangnya potensi mahasiswa agar menjadi manusia yang beriman dan bertakwa kepada Tuhan Yang Maha Esa, berakhlak mulia, sehat, berilmu, cakap, kreatif, mandiri, serta menjadi warga negara yang demokratis dan bertanggungjawab." Dengan mengacu pada tujuan pendidikan di perguruan tinggi seperti ini, buku-buku PAI yang disusun oleh para dosen PAI Untirta Nampak masih mengandung berbagai kelemahan, dan belum sepenuhnya menggambarkan tujuan pendidikan, termasuk PAI. Bahasan dalam buku-buku tersebut nampak lebih dominan mengarah pada frasa "takwa kepada Tuhan Yang Maha Esa" dan "berilmu". Sementara tujuan lain dalam membangun manusia yang "berakhlak mulia", "sehat", "cakap", "kreatif", "mandiri", dan "bertanggung jawab" nyaris sama sekali tidak disentuh, karena dipandang tidak menjadi tujuan spesifik pendidikan agama.

Bahkan, dimensi ketakwaan terhadap Tuhan YME pun nampak lebih diarahkan pada kesalehan ritual, sebagainama nampak dari dominannya tema-tema tentang fikih bersuci, salat, zakat, puasa ramadhan, dan haji. Bahasan tentang ini baru dihindarkan pada buku-buku bahan ajar di semester ke-2 yang memang diarahkan pada pembahasan tema-tema aktual keagamaan. Tetapi itu pun, sayangnya, hanya menyentuh secara tidak langsung pada tujuan pendidikan PAI itu sendiri. Sementara dimensi "berilmu" dielaborasi secara sangat luas dengan mengembangkan berbagai wacana keagamaan aktual, seperti restorasi Indonesia versi Islam, Islam dalam konteks budaya Nusantara, Islam dan pluralitas bangsa, Islam dan ekonomi 
koperasi, hukum Islam dalam konteks sistem hukum nasional, poligami, mut'ah, dan milkul yamin, mengenal politik dan ketatanegaraan Islam, wakaf saham dalam perspektif fikih, seni budaya dalam relasi tasawuf, dan sebagainya.

Tetapi berbagai tulisan itu sepertinya belum secara optimal memanfaatkan buku dan kitab serta karya-karya cendekiawan Muslim dari berbagai periode (klasik dan modern) yang disebut menjadi sumber referensi. Alih-alih mengkaji pemikiran para tokoh yang karyakaryanya disebut, penulis bahkan seringkali terjebak pada wacana tunggal yang diklaimnya sebagai "Islami". Padahal tidak sedikit buku dan pendapat yang justru menyatakan sebaliknya. Berdasarkan sumber bacaan disebut banyak sekali buku yang justru mengandung pendapat yang menolaknya, seperti karya-karya Al-Mawardi, Ibn Khaldun, Yusuf Qardhawi, Nurcholish Madjid, Munawir Sjadzali, Budhy Munawar Rahman, dan lain-lain yang disebutnya dalam buku-buku rujukan.

Alih-alih memberikan pemahaman yang utuh kepada mahasiswa, tulisan-tulisan seperti ini justru sama sekali tidak mencerahkan, baik secara akademik, politik, kultural, dan keagamaan. Sementara bahasan dan wacana yang sangat penting dan berkaitan secara langsung dengan spirit perkulian Pendidikan Agama Islam seperti tema tentang etika politik dalam Islam justru tidak ditawarkan menjadi tema diskusi dan tidak dituliskan menjadi bab tersendiri. Padahal, sebagai landasan etik dan moral, justru kajian seperti ini yang lebih penting dibahas.

\section{PENUTUP}

Berdasarkan hasil penelitian, paradigma keagamaan yang diusung nampak beragam, dan cenderung memuat ketiga paradigma, yakni moderat, radikal, dan liberal. Beberapa tulisan tentang tauhid cenderung skripturalis, dan didasarkan pada karya-karya Ibn Taymiyah dan Muhammad ibn Abdul Wahab. Dalam hal tertentu, bahan ajar PAI juga berusaha melakukan kontekstualisasi ajaran dengan mengangkat kasus-kasus aktual keagamaan dan memberikan respons cukup adil terhadapnya.

Namun hal-hal tertentu para penulis "tidak berhasil" melakukan eksplorasi akademik terhadap tujuan pembelajaran PAI di perguruan tinggi, yakni "berkembangnya potensi mahasiswa agar menjadi manusia yang beriman dan bertakwa kepada Tuhan Yang Maha Esa, berakhlak mulia, sehat, berilmu, cakap, kreatif, mandiri, serta menjadi warga negara yang demokratis dan bertanggung jawab". Hal ini diindikasikan oleh "sepi"-nya bahasan tentang kesehatan dalam perspektif Islam, paradigma keilmuan dalam Islam, pentingnya kecakapan hidup bagi pengembangan kemandirian ekonomi, eksplorasi dimensi kreatif dalam nilai keagamaan Islam, dan seterusnya. Di tengah pentingnya spirit kemandirian dalam tujuan perkuliahan PAI, juga sama sekali tidak tersedia tema yang memberikan basis teologis tentang kerja, seperti Teologi Kerja, Teologi Ekonomi, Etos Kerja dalam Islam, dan sebagainya. Bahkan, terkait dengan "menjadi warga negara yang demokratis", salah satu tulisannya bahkan cenderung menolak demokrasi yang disebutnya sebagai tidak sesuai dengan sistem ketatanegaraan Islam yang disebutnya bukan monarki, bukan republik, bukan kekaisaran, dan bukan federasi.

Hal lain yang cukup krusial dalam bahasan tentang tauhid dalam doktrin keagamaan Islam adalah perspektifnya yang didasarkan atas pemikiran Ibn Taymiyah dan Muhammad Ibn Abdul Wahab yang dikenal skripturalistik dan tekstual. Lebih dari itu, prinsip-prinsip tauhid ini tidak memiliki akar kultural yang kuat dalam kehidupan keagamaan Islam di Indonesia yang disebut Ahl al-Sunnah wal-Jama'ah berdasarkan pemikiran Abu Hasan Al-Asy'ari dan Abu Manshur al-Maturidi dalam bidang akidah, mengambil salah satu dari imam yang 4 (Maliki [Malik ibn Anas], Hanafi [Imam Abu Hanifah], al-Syafii [Muhammad ibn Idris Al-Syafii, Imam Syafii], dan Ahmad ibn Hanbal) dalam masalah fikih, mengambil Imam Al-Ghazali dan Abd al-Qadir Al-Jaylani dalam tasawuf, serta mengikuti pemikiran Al-Ahkam Al-Sulthaniyah Abu Al-Hasan Al-Mawardi dalam masalah politik. Dalam konteks keyakinan keagamaan, refleksi pemahaman keagamaan ini nampak dari adanya keyakinan terhadap "Sifat Duapuluh", kuatnya tradisi tarekat (tasawuf), praktik peribadatan yang bersumber pada pemikiran Imam Mazhab (terutama Al-Syafii), serta penerimaan yang kokoh terhadap negara sistem pemerintahan di 
Indonesia yang berdasarkan pada Pencasila dan UUD 1945 dengan berpedoman pada pemikiran politik Islam Al-Mawardi. Sayangnya, tidak satu pun buku PAI karya kolektif pada dosen di Untirta yang menyebut dan melakukan elaborasi seperlunya terhadap pemikiran yang menjadi pemahaman umum di kalangan umat Islam di Indonesia ini.

Berasarkan temuan penting kajian ini, dosen-dosen PAI di Untirta nampaknya perlu melakukan transformasi sistem perkuliahan dengan menawarkan tema-tema keagamaan yang lebih aktual dan sesuai dengan kebutuhan keagamaan dan spitual mahasiswa sebagaimana diamanatkan oleh UU tentang Perguruan Tinggi. Karena itu, para dosen perlu meninjau kembali silabus perkuliahan dan bahan ajar, dengan memasukkan tema-tema terkait dengan spirit keilmuan dalam Islam, Teologi Kerja, etos kerja dalam Islam, membangun masyarakat yang sehat dan bersih dalam perspektif Islam, Islam dan kemandirian ekonomi, membangun manusia kreatif dalam bingkai nilai ketuhanan, dan sebagainya. Masuknya tema-tema ini diarahkan pada spirit kehidupan, bahwa apa pun yang dilakukan oleh manusia akan bernilai amal saleh dan akan dipertanggung jawabkan di hari kemudian. Pendidikan Agama Islam di perguruan tinggi umum sama sekali tidak dimaksudkan untuk melahirkan orang yang ahli dalam agama, tetapi "sekedar" memberikan perspektif agar profesi dan kehidupan yang dipilihnya kelak dibangun berdasarkan spirit dan dorongan keagamaan dan semangat ketakwaan kepada Allah swt, Tuhan Yang Maha Esa.

Selain itu, dalam kerangka transformasi sistem perkuliahan, materi dan bahan ajar PAI perlu disusun dalam perspektif yang lebih luas. Dalam hal ini, patut dipertimbangkan tawaran metodologi studi Islam yang disampaikan Kuntowijoyo ke dalam 3 matra utama: dari abstrak ke kongkret, dari ideologi ke ilmu, dan dari subjek ke objek. Dengan perspektif ketiga matra ini seraca utuh, maka proses reaktualisasi Islam akan memunculkan 5 program reinterpretasi: 1) perlu dikembangkan penafsiran sosial-struktural lebih daripada penafsiran individual ketika memahami ketentuan yang ada dalam kitab suci; 2) mengubah cara berpikir subjektif ke cara berpikir objektif; 3) mengubah
Islam yang normatif menjadi teoretik; mengubah pemahaman yang a-historis menjadi historis; dan 4) merumuskan formulasiformulasi wahyu yang bersifat umum menjadi formulasi yang bersifat spesifik dan empirik.

Hanya dengan cara ini tawaran Kuntowijoyo yang menarik ini dapat direalisasikan; dan dengan cara ini pula Pendidikan Agama Islam di Perguruan Tinggi dapat menjangkau tujuannya yang mulia, yakni “... berkembangnya potensi mahasiswa agar menjadi manusia yang beriman dan bertakwa kepada Tuhan YME, berakhlak mulia, sehat, berilmu, cakap, kreatif, mandiri, serta menjadi warga negara yang demokratis dan bertanggung jawab". Wallahu a'lam.

\section{DAFTAR PUSTAKA}

Abdullah, A. (2016) 'Gerakan Radikalisme Dalam Islam: Perspektif Historis', ADDIN, 10(1), p. $1 . \quad$ doi: 10.21043/addin.v10i1.1127.

Arobi, M. Z. (2020) Islamisme ala Kaum Muda Kampus: Dinamika Aktivisme Mahasiswa Islam di UGM dan UI di Era PascaSoeharto. Yogyakarta: Gajah Mada University Press.

Chanifudin, C. and Nuriyati, T. (2020) 'Integrasi Sains dan Islam dalam Pembelajaran', ASATIZA: Jurnal Pendidikan, 1(2), pp. 212-229. doi: 10.46963/asatiza.v1i2.77.

Erowati, D. (2018) 'Islam Liberal di Indonesia (Pemikiran dan Pengaruhnya Dalam Pemikiran Politik Islam di Indonesia', Jurnal Ilmiah Ilmu Pemerintahan, 2(2), pp. 18-32. doi: 10.14710/jiip.v2i2.2119.

Faqihuddin, A. (2021) 'Islamic Moderate In Indonesia', Ar-Risalah, 12(1), pp. 107118. doi: 10.34005/alrisalah.v12i1.1238.

Hakim, L. (2011) 'Mengenal Pemikiran Islam Liberal', Fakultas Ushuluddin IAIN ArRaniry, 14(128), pp. 179-198.

Hamad, I. (2007) 'Lebih Dekat dengan Analisis Wacana', Mediator: Jurnal Komunikasi, 8(2), pp. 325-344. doi: 10.29313/mediator.v8i2.1252.

Hefni, W. (2020) 'Moderasi Beragama dalam 
Ruang Digital: Studi Pengarusutamaan Moderasi Beragama di Perguruan Tinggi Keagamaan Islam Negeri', Jurnal Bimas Islam, 13(1), pp. 1-22. doi: 10.37302/jbi.v13i1.182.

Hidayatullah, P. U. S. (2017) "Api dalam Sekam” Keberagamaan Muslim Gen Z, SurveyNasional tentang Keberagamaan di Sekolah dan Universitas di Indonesia. Jakarta.

Jamil, M. (2017) 'Hukum dan Radikalisme Agama di Indonesia', Majalah NUSANTARA IKPMDI-Yogyakarta. Available at: http://dx.doi.org/10.31219/osf.io/3k7gf.

Khamid, N. (2016) 'Bahaya Radikalisme terhadap NKRI', Millati: Journal of Islamic Studies and Humanities, 1(1), p. 123. doi: 10.18326/mlt.v1i1.123-152.

Kurzman, C. (ed.) (2001) Wacana Islam Liberal: Pemikiran Islam Kontemporer tentang Isu-Isu Global. Jakarta: Paramadina.

M. Syamsul Huda and Djalal, A. (2020) 'Telaah kembali Islam Moderat dan Islam Radikal dalam perspektif generasi milenial', Universitas Islam Negeri Sunan Ampel Surabaya. Available at: http://digilib.uinsby.ac.id/39374/.

Munir, A. et al. (2020) Literasi Moderasi Beragama di Indonesia. Edited by Sirajuddin. Bengkulu: CV. Zigie Utama.

Naim, N. (2021) 'Ikhtiar Membangun Keberagamaan Moderat', in Moderasi Beragama dalam Bernegara. Tulungagung: Akademia Pustaka. Available at: http://repo.uinsatu.ac.id/id/eprint/20875.

Natalia, A. (2016) 'Faktor-faktor penyebab radikalisme dalam beragama (Kajian Sosiologi Terhadap Pluralisme Agama di Indonesia)', Al-Adyan, 11(1), pp. 1-11. Available at: https://media.neliti.com/media/publicatio ns/177630-ID-faktor-faktor-penyebabradikalisme-dalam.pdf.

Qodir, Z. (2018) 'Kaum Muda, Intoleransi, dan Radikalisme Agama', Jurnal Studi
Pemuda, 5(1), p. 429. doi: 10.22146/studipemudaugm.37127.

Raco, J. (2018) Metode penelitian kualitatif: jenis, karakteristik dan keunggulannya. Jakarta: Grasindo. doi: 10.31219/osf.io/mfzuj.

Rizky, F. U. and Syam, N. (2021) 'Komunikasi Persuasif Konten Youtube Kementerian Agama dalam Mengubah Sikap Moderasi Beragama', Jurnal Ilmu Komunikasi, 11(1), pp. 16-33. doi: 10.15642/jik.2021.11.1.16-33.

Rohman, D. A. (2020) Narasi moderasi Islam Indonesia dalam media cetak: Studi tentang artikel Moderasi Islam Perspektif Kementerian Agama Dalam Koran Republika Periode 2017-2019. UIN Sunan Gunung Djati Bandung. Available at:

http://digilib.uinsgd.ac.id/id/eprint/33308

Salim, N., Suryanto, S. and Widodo, A. (2018) 'Pencegahan Paham Radikalisme dan Terorisme Melalui Pendidikan Multikulturalisme pada Siswa MAN Kediri I', Jurnal ABDINUS: Jurnal Pengabdian Nusantara, 2(1), pp. 99-107.

Singgih, E. G., Darmawan, C. and Dkk (2021) Dialektika Pendidikan dan Agama di Era Kontemporer. Edited by B. Melmambessy et al. Yogyakarta: Litera.

Wahyuddin, A. et al. (2009) Pendidikan Agama Islam untuk Perguruan Tinggi. Jakarta: Grasindo.

Wibowo, P. (2014) 'Penguatan, Sinkronisasi, Harmonisasi, Integrasi Pelembagaan Dan Pembudayaan Pancasila Dalam Rangka Memperkokoh Kedaulatan Bangsa', in Prosiding Kongres Pancasila VI. Yogyakarta: niversitas Gajah Mada.

Zarkasyi, H. F. (2010) 'Warna Liberalisme dalam Islam dan Katolik, Samakah?', Republika.co.id, 17 April. Available at: https://www.republika.co.id/berita/11163 2/warna-liberalisme-dalam-islam-dankatolik-samakah diunduh 14 maret 2021.

Zubaedi (2013) Pengembangan Masyarakat: Wacana dan Praktik. Jakarta: Kencana. 